\title{
Live Birth Indicator
}

National Cancer Institute

\section{Source}

National Cancer Institute. Live Birth Indicator. NCI Thesaurus. Code C156589.

An indication as to whether the subject has delivered live-born offspring. 